\title{
The earliest centres of pottery origin in the Russian Far East and Siberia: review of chronology for the oldest Neolithic cultures
}

\author{
Yaroslav V. Kuzmin \\ Pacific Institute of Geography, Vladivostok, Russia \\ ykuzmin@tig.dvo.ru
}

\begin{abstract}
The earliest pottery from the Russian Far East, Osipovka and Gromatukha cultural complexes, was radiocarbon-dated to c. 13300-12300 BP. In Siberia, the earliest pottery is known from the Ust-Karenga complex, dated to c. 11200-10800 BP. The Osipovka and Gromatukha complexes belong to the Initial Neolithic, and they are contemporaneous with the earliest Neolithic cultures in southern China and Japan. In spite of the very early emergence of pottery in the Russian Far East, there is no evidence of agriculture at the beginning of the Neolithic, and subsistence remains based on hunting and fishing, including anadromous salmonids in the Amur River and its tributaries.

IZVLEČEK - Najzgodnejša keramika z ruskega Daljnega vzhoda, iz kulturnih kompleksov Osipovka in Gromatukha, je radiokarbonsko datirana okoli 13300 do 12300 BP. Najzgodnejša znana keramika iz Sibirije je iz kompleksa Ust-Karenga, datirana pa je okoli 11200 do 10800 BP. Kompleksa Osipovka in Gromatukha pripadata začetnemu neolitiku in sta sočasna z neolitskimi kulturami na južnem Kitajskem in Japonskem. Kljub zelo zgodnjemu pojavu keramike na ruskem Daljnem vzhodu pa ni dokazaov o kmetovanju na začetku neolitika. Način preživljanja še vedno temelji na lovu in ribolovu vključno lososov (anadromous salmonids) $v$ reki Amur in njenih pritokih.
\end{abstract}

KEY WORDS - pottery; initial Neolithic; radiocarbon dating; Russian Far East; Siberia

\section{INTRODUCTION}

The aim of this review is to present an updated chronology of the oldest Neolithic cultural complexes in the Russian Far East and Siberia, along with a brief description of the earliest pottery and some suggestions on the palaeoeconomy. The prehistory of the Russian Far East covers the Amur River basin, Primorye (Maritime) Province, and Sakhalin Island (Suslov 1961). The term "Neolithic" as elsewhere in Northeast Asia means the presence of pottery (e.g. Chard 1974.63-64; Barnes 1999.69). The archaeological study of the earliest Neolithic sites in the Russian Far East was initiated in the late 1920s by Gerasimov (1928) and was continued in 1935 by Okladnikov (1936; 1980). However, until the mid-1970s the oldest Neolithic complex in the lower stream of the Amur River, Osipovka, was thought to be asso- ciated with the Mesolithic (e.g. Okladnikov and Derevianko 1973). Since the mid-1970s, the stratigraphic association of microblades, bifaces, and pottery has been recognized at Gasya, the key site of the Osipovka complex (Derevianko and Medvedev 1992a. 13; 1993.24-25). Pottery-associated charcoal from Gasya was radiocarbon (below $-{ }^{14} \mathrm{C}$ ) dated to $\mathrm{c}$. 13000 BP (Okladnikov and Medvedev 1983).

The second earliest Neolithic complex of the Russian Far East, Gromatukha in the middle reaches of the Amur River basin, was excavated in the 1960s (Okladnikov and Derevianko 1977), but was ${ }^{14} \mathrm{C}$ dated only in the late 1990 s and in 2000 . The ${ }^{14} \mathrm{C}$ age of the Gromatukha culture at c. $12300 \mathrm{BP}$ and possibly up to c. $13200 \mathrm{BP}$, is quite close to the age 
of the Osipovka complex. The third earliest Neolithic complex, Ust-Karenga, was identified in the 1970s in the middle reaches of the Vitim River in Eastern Siberia; excavations are on-going (Vetrov 1985; 2000). The earliest pottery derives from cultural layer 7 and was ${ }^{14} \mathrm{C}$-dated to c. $11200-10800 \mathrm{BP}$ (Vetrov 1995). This is the earliest pottery outside of the Russian Far East; Ust-Karenga represents the earliest Neolithic complex in Siberia (Kuzmin and Orlova 2000).

\section{MATERIALS AND METHODS}

For the purposes of this review, published archaeological and palaeogeographical data are used, including geoarchaeological and geochronological data obtained by the author (Kuzmin 1995; 1997; 1998a; 1998b; Kuzmin and Jull 1997; Kuzmin et al. 1997; 1998a; O'Malley et al. 1999; Jull et al. 2001). ${ }^{14} \mathrm{C}$ dating is a particular focus of this study. Different kinds of carbon compounds were ${ }^{14} \mathrm{C}$-dated: a) charcoal from hearths; b) dispersed charcoal from cultural layers; and c) plant fibre from temper in pottery. ${ }^{14} \mathrm{C}$ dates were calibrated using the most recent software CALIB rev. 4.3 (Quaternary Isotope Lab, University of Washington, Seattle, WA, USA) (Stuiver and Reimer 1993; Stuiver et al. 1998). When calibrated, all possible intervals for 2 sigma $( \pm 2 \sigma)$ were combined up and rounded up to the next 10 years. When ${ }^{14} \mathrm{C}$ dates determined in Russia, the USA, and Japan, are compared with dates from China, the Chinese dates have been recalculated for Libby's ${ }^{14} \mathrm{C}$ half-life value (5568 years). For independent control of directly ${ }^{14} \mathrm{C}$-dated pottery, a few thermoluminescence (TL) dates of the pottery were generated (Kuzmin et al. 2001).

The ${ }^{14} \mathrm{C}$ dating of charcoal was conducted using the standard procedure (e.g. Taylor 1987). As for direct $14 \mathrm{C}$ dating of pottery temper by the accelerator mass spectrometry (AMS) technique, a special protocol was developed (O'Malley et al. 1999). First of all, pottery samples were subdivided into exterior and interior parts. The pottery was then powdered using pestle and mortar, and pre-treated using the standard acid- alkali-acid procedure. The next step was pottery combustion on a vacuum line employing two different substances: a) with copper oxide, and b) with oxygen. Two temperature combustion regimes, $400^{\circ} \mathrm{C}$ for one hour and $800^{\circ} \mathrm{C}$ for 30 minutes, were used to extract carbon. Additionally, bulk pottery, i.e. without separation into exterior and interior parts, was combusted at c. $1000^{\circ} \mathrm{C}$ for 10 minutes with copper oxide. The evaluation of different ways of carbon extraction for AMS dating, made by comparison of temper dates with charcoal dates from the same cultural layer, leads to the conclusion that the low temperature fraction $\left(400^{\circ} \mathrm{C}\right)$ of the internal carbon-rich portion of plant fibre-tempered pottery, combusted with oxygen, provides the best estimate of the age of ceramics ( $O$ 'Malley et al. 1999.23). It seems that in this way we were able to release carbon mostly from temper and to reduce the release of carbon from clay. The carbon dioxide, obtained after combustion, was converted to graphite for AMS ${ }^{14} \mathrm{C}$ dating.

\section{THE EARLIEST POTTERY IN THE RUSSIAN FAR EAST AND EASTERN SIBERIA}

At the present stage of research, three principal earliest Neolithic cultural complexes (in Russian archaeological terminology - cultures), Osipovka, Gromatukha, and Ust-Karenga, have been distinguished in the Russian Far East and Siberia (Fig. 1). The Osipovka site itself was discovered and partially excavated in the late 1920s (Gerasimov 1928), and at the time of intensification of the excavations in the early

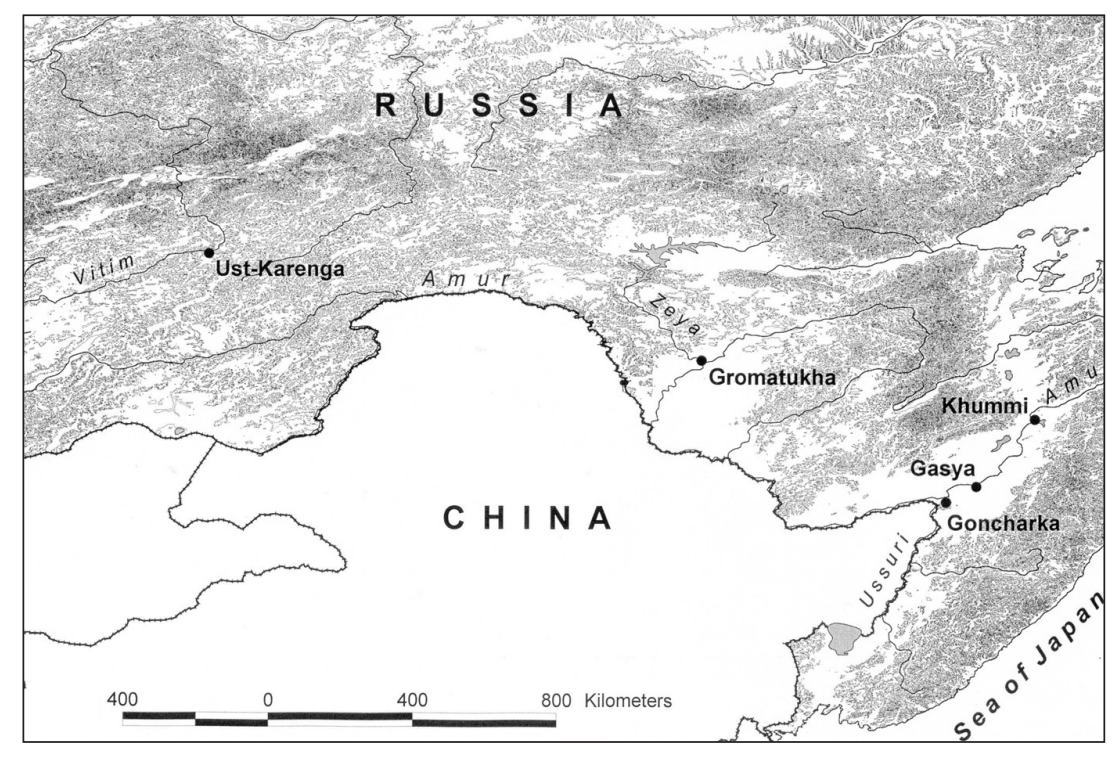

Fig. 1. Location of the earliest Neolithic cultural complexes in the Russian Far East and Siberia. 


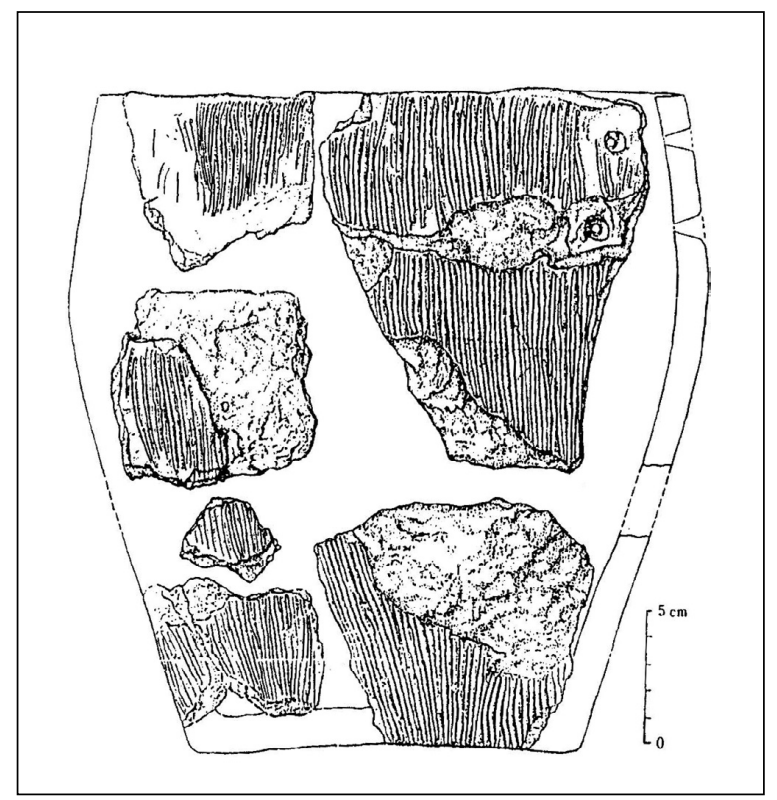

Fig. 2. The Osipovka complex pottery from the Gasya site (after Derevianko and Medvedev 1995).

1950s by Okladnikov and his students (e.g. Okladnikov 1958), the site had been severely damaged by modern agricultural and building construction activities. Today, it is completely destroyed, and further excavations are impossible. We now have three main sites belong to the Osipovka complex, Gasya, Khum$\mathrm{mi}$, and Goncharka, all located in the lower reaches of the Amur River basin. The sites of the Gromatukha complex occur in the central part of the Amur River basin, and the Ust-Karenga cultural complex sites are located in the Vitim River area.

\section{The Osipovka complex}

The Gasya site was excavated from the 1960s to the 1980 s, but only preliminary results of the excavations have been published (Derevianko and Medvedev 1992a; 1992b; 1993; 1994; 1995a; 1995b). The earliest pottery, represented by a few fragments, was first discovered in 1975 near the bottom of the cultural layer, in association with a Mesolithic-like laurel-leaf point (Derevianko and Medvedev 1992a. 13-14). In 1980, larger pieces of pottery (about 20 fragments) were found in association with charcoal (Derevianko and Medvedev 1993.24), later ${ }^{14} \mathrm{C}-\mathrm{da}-$ ted to c. $13000 \mathrm{BP}$. The reconstruction of a pot allows us to reveal the general features of the earliest ceramics (Fig. 2). The pot is of conoidal shape with a flat base, and 25-27 cm high. The thickness of the walls is $1.2-1.7 \mathrm{~cm}$, and the thickness of the base is $1.5-1.7 \mathrm{~cm}$. The estimated volume of the pot is approximately 5.5-6 litres. The design is quite simple, and is represented by vertical grooves on the exter- nal surface. The colour of the pot is black, and traces of soot were recognized on both sides of the pot. The pottery is plant fibre-tempered (Zhushchikhovskaya 1997a; 1997b).

At the Khummi site, about 20 pottery fragments were found in 1992 and 1993 (Lapshina 1998; 1999) (Fig. $3)$. It has not been possible to make reconstructions of the pottery because of both the small number and small size of the fragments. The thickness of the fragments is $0.7-1.0 \mathrm{~cm}$. There are grooves on both sides of the pottery sherds; however, there is no real design. The colour of the pot is blackish-grey. Similar to the Gasya site, the pottery is plant fibre-tempered; some grog inclusions were considered to be accidental (Lapshina 1998.195).

At the Goncharka site, several hundred fragments of pottery have been found, and this has allowed us to reconstruct four flat based vessels (Shevkamud 1997). The pottery was subdivided into two groups.

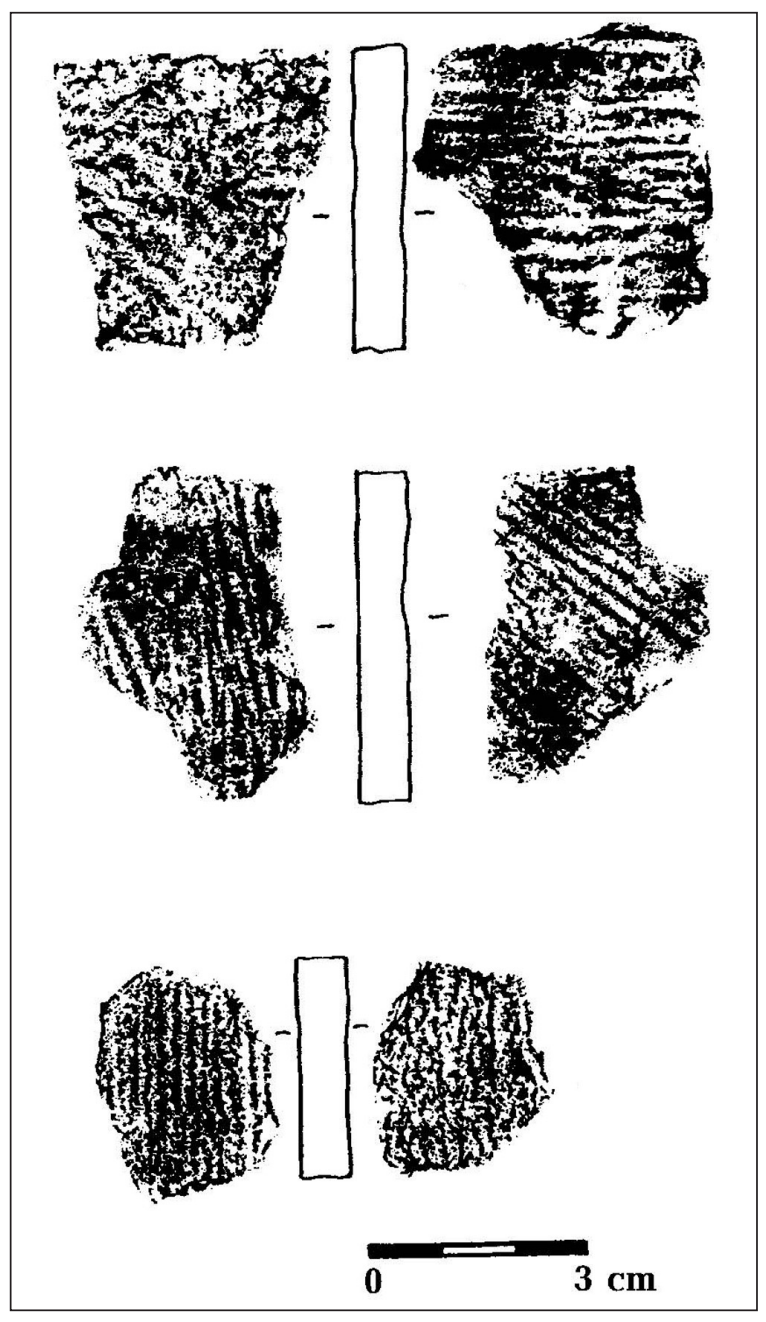

Fig. 3. The Osipovka complex pottery from the Khummi site (after Lapshina 1999). 


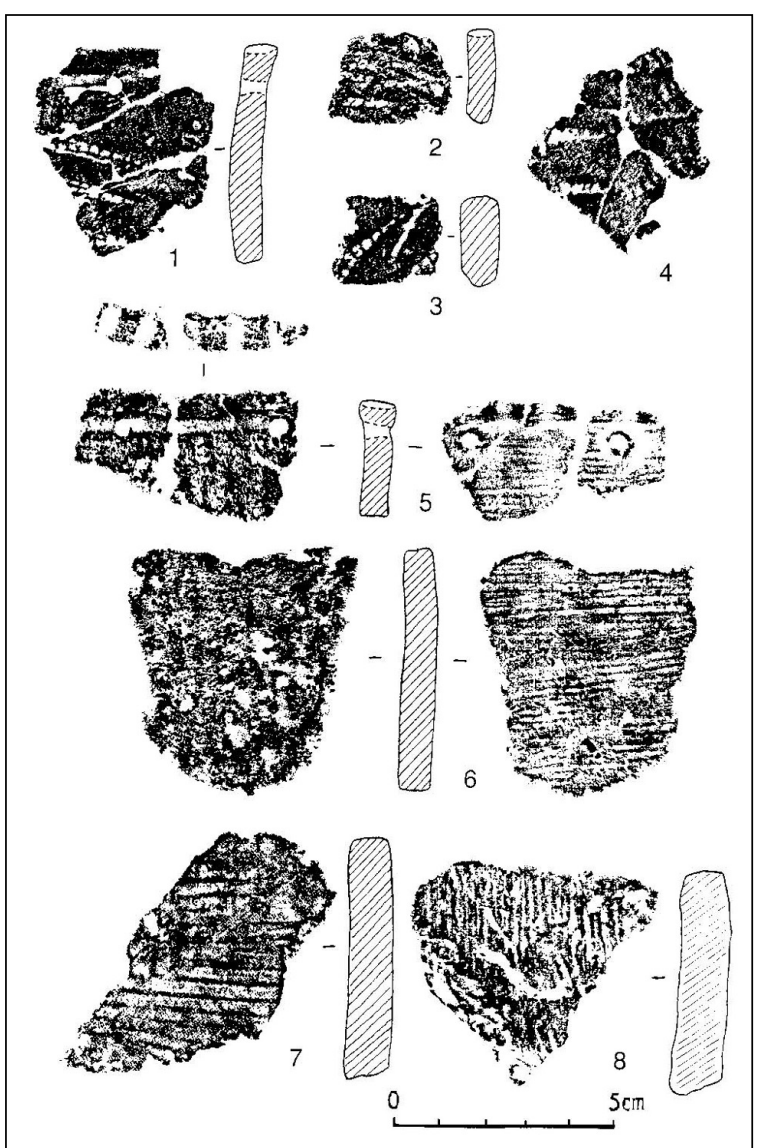

Fig. 4. The Osipovka complex pottery from the Goncharka site (after Shevkamud 1997).

For the first group (Fig. 4: 5-6), the thickness of wall fragments is $0.7-0.8 \mathrm{~cm}$. There are horizontal internal scratches made by either bundles of grass or a comb. Wave-like indentations, made by pressing sticks or cords on to the surface, occur on the rims. Some sherds are decorated with comb-like vertical zigzag impressions (Fig. 4: 1-2). The second group (Fig. 4: 1-4, 7-8) has external traces of a comb-like instrument or cord impressions. The wall fragments are $0.7-1.0 \mathrm{~cm}$ thick. The design is well-developed, and is represented by a vertical zigzag made with a comb (Fig. 4: 3-4). For both groups, there is no evidence of organic temper in the ceramic paste. This is in contrast to the other Osipovka complex sites, Gasya and Khummi.

\section{The Gromatukha complex}

Okladnikov and Derevianko (1977) described the Gromatukha cultural complex after excavations in the 1960s. At the key site of this complex, Gromatukha, several dozen plant fibre-tempered pottery fragments were recovered from the lower part of the cultural layer. The reconstructed vessel has a flat base (Okladnikov and Derevianko 1977.97); the walls are $0.7-0.8 \mathrm{~cm}$ thick. The pottery has grooves on its internal and external sides (Figs. 5, 6). The temper in the form of plant fibre blades is visible on the surface of the sherds.

\section{The Ust-Karenga complex}

The Ust-Karenga cultural complex is represented by more than 30 sites (Vetrov 1997). The pottery from the earliest Neolithic component of the key site, UstKarenga (layer 7), is very different from the earliest pottery in adjacent Eastern Siberia and the Amur River basin (Vetrov 1985; 1995). Several hundred fragments have been excavated, and about 20 pots have been reconstructed (Fig. 7). There are sharp based parabolic vessels of two sizes, one $12-14 \mathrm{~cm}$ in diameter and $16-18 \mathrm{~cm}$ high, and the other 20 $\mathrm{cm}$ in diameter and $35-38 \mathrm{~cm}$ high. The walls are $0.4-0.5 \mathrm{~cm}$ thick. The design is quite elaborate, and represented by comb decorations, zigzag, herringbone, and cogged stamps (Fig. 8). The pottery is plant fibre tempered.

\section{CHRONOLOGY OF THE EARLIEST NEOLITHIC COMPLEXES}

The results of ${ }^{14} \mathrm{C}$ dating of charcoal from hearths and concentrations of small charcoal particles in the cultural layers, as well as of pottery temper (Kuz-

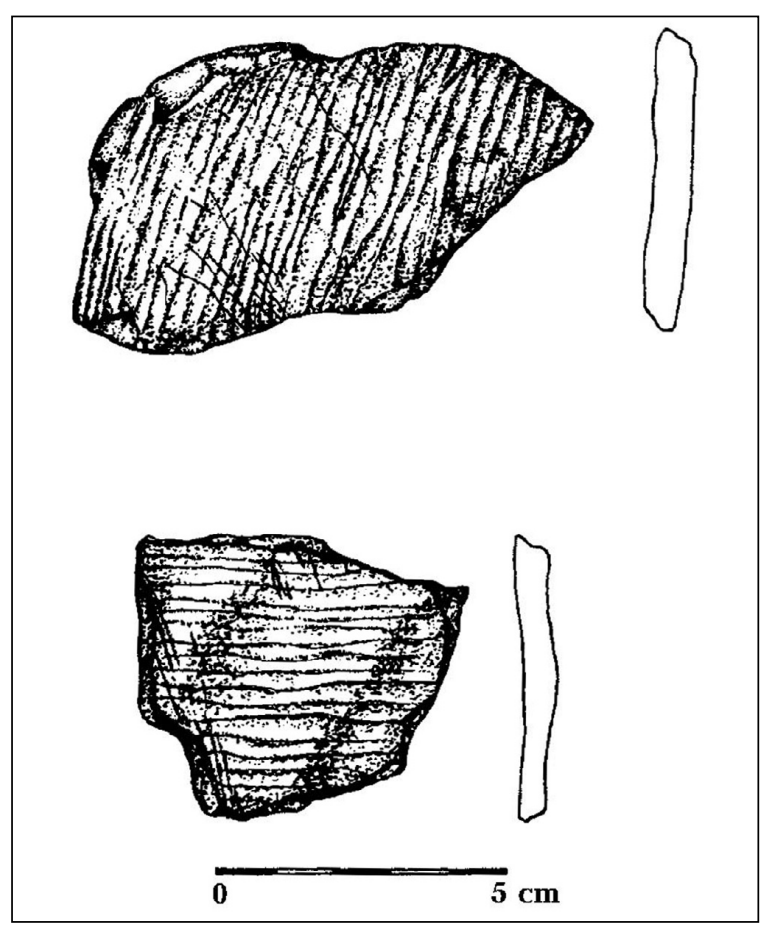

Fig. 5. The Gromatukha complex pottery from the Gromatukha site (after Jull et al. 1998). 


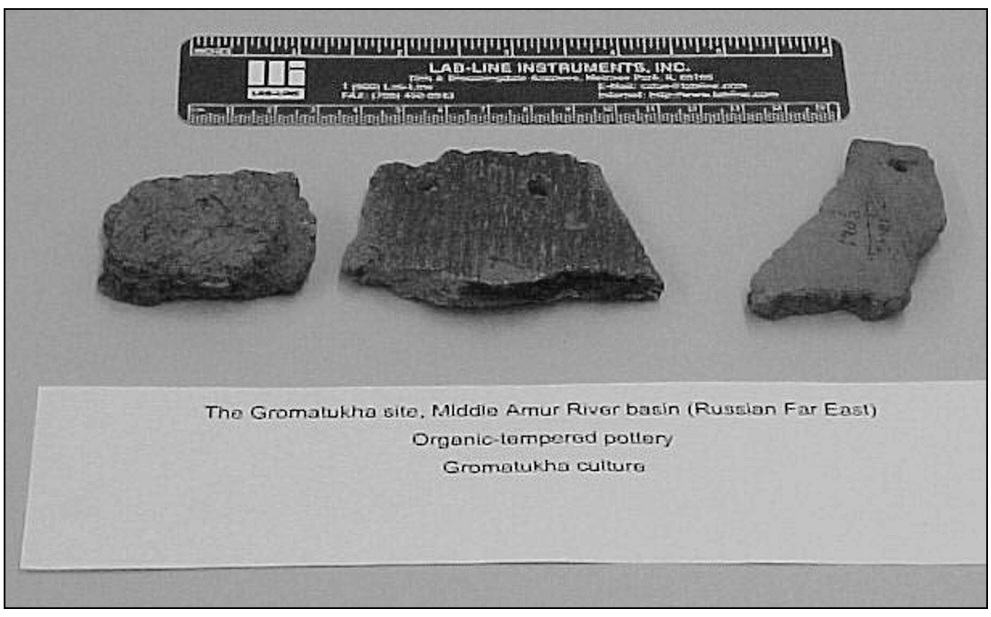

Fig. 6. The Gromatukha complex pottery from the Gromatukha site.

min and Jull 1997; Kuzmin 1998; Kuzmin et al. 1997; 1998a; O'Malley et al. 1999; Jull et al. 2001), are presented in Table 1. This dataset is state-of-theart as of early 2002. At the Gasya site, the earliest pottery-associated charcoal is dated to c. 14200$12500 \mathrm{cal} \mathrm{BC}$. At the Khummi site, the earliest charcoal date is c. $14500-13000 \mathrm{cal} \mathrm{BC}$, and at the Goncharka site it is c. 13600-12 200 cal BC. Unfortuna- tely, for these sites we do not have ${ }^{14} \mathrm{C}$ dates run on pottery temper using combustion with oxygen at $400^{\circ} \mathrm{C}$. There are other dates, obtained by using combustion of the internal part of sherds with copper oxide: at $400^{\circ} \mathrm{C}-9020 \pm 65 \mathrm{BP}(\mathrm{AA}-$ 20934) for the Gasya site, and at $800^{\circ} \mathrm{C}-11915 \pm 80 \mathrm{BP}(\mathrm{AA}-20932)$ for the Khummi site. Bulk temper dates are $11905 \pm 80 \mathrm{BP}$ for Gasya and $12010 \pm 100$ BP for Khummi (O'Malley et al. 1999).

For the Gromatukha and Ust-Karenga sites, we have charcoal dates and pottery temper dates, run on temper using combustion with oxygen at $400^{\circ} \mathrm{C}\left(O^{\prime}\right.$ Malley et al. 1999) (Tab. 1). The earliest charcoal date for Gromatukha

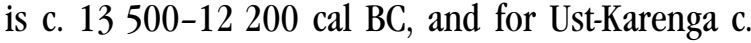
11800-11 $100 \mathrm{cal} \mathrm{BC}$. The pottery temper date for the Gromatukha site is even older at c. 14600$12900 \mathrm{cal}$ BC. For Ust-Karenga, the pottery temper dates are quite close to those run on charcoal.

\begin{tabular}{|c|c|c|c|c|c|}
\hline $\begin{array}{l}\text { Region, } \\
\text { complex }\end{array}$ & Site & $\begin{array}{c}{ }^{14 C} \text { date, } \\
\text { yr BP }\end{array}$ & Lab No. & $\begin{array}{c}\text { Calibrated age, } \\
\text { cal BC }\end{array}$ & Reference \\
\hline \multicolumn{6}{|c|}{ Russian Far East } \\
\hline \multirow[t]{12}{*}{ Osipovka } & Gasya & $12960 \pm 120^{*}$ & LE-1781 & $14160-12530$ & Kuzmin and Jull 1997 \\
\hline & & $11340 \pm 60^{*}$ & GEO-1413 & $11830-11080$ & Kuzmin 1998 \\
\hline & & $10875 \pm 90^{*}$ & AA-13391 & $11190-10690$ & Kuzmin and Jull 1997 \\
\hline & Khummi & $13260 \pm 100^{*}$ & $A A-13392$ & $14500-12950$ & Kuzmin and Jull 1997 \\
\hline & & $12425 \pm 850^{*}$ & SOAN-3583 & $15040-10740$ & Kuzmin 1998 \\
\hline & & $10345 \pm 110^{*}$ & AA-13391 & $10880-9740$ & Kuzmin and Jull 1997 \\
\hline & Goncharka & $12500 \pm 60^{*}$ & LLNL-102169 & $13600-12210$ & Jull et al. 2001 \\
\hline & & $12055 \pm 75^{*}$ & AA-25437 & $13400-11720$ & Jull et al. 2001 \\
\hline & & $10590 \pm 60^{*}$ & LLNL-102168 & $10990-10240$ & Jull et al. 2001 \\
\hline & & $10280 \pm 70^{*}$ & $A A-25438$ & $10790-9750$ & Jull et al. 2001 \\
\hline & & $10280 \pm 70^{*}$ & AA-25439 & $10790-9750$ & Jull et al. 2001 \\
\hline & & $9890 \pm 230^{*}$ & GaK-18981 & $10380-8650$ & Jull et al. 2001 \\
\hline \multirow[t]{4}{*}{ Gromatukha } & Gromatukha & $12340 \pm 60^{*}$ & $A A-36079$ & $13530-12160$ & Jull et al. 2001 \\
\hline & & $9895 \pm 50^{*}$ & $A A-36447$ & $9600-9250$ & Jull et al. 2001 \\
\hline & & $13310 \pm 100^{* *}$ & $A A-20940$ & $14560-13070$ & O'Malley et al. 1999 \\
\hline & & $13240 \pm 85^{* *}$ & AA-20939 & $14460-12920$ & O'Malley et al. 1999 \\
\hline \multicolumn{6}{|c|}{ Eastern Siberia } \\
\hline \multirow[t]{4}{*}{ Ust-Karenga } & Ust-Karenga & $11240 \pm 80^{*}$ & GIN-8066 & $11820-11050$ & Vetrov 1995 \\
\hline & & $10750 \pm 60^{*}$ & GIN-8067 & $11030-10490$ & Vetrov 1995 \\
\hline & & $11065 \pm 70^{* *}$ & $A A-38101$ & $11240-10720$ & This paper \\
\hline & & $10600 \pm 100^{* *}$ & $A A-21378$ & $11000-10210$ & Jull et al. 2000 \\
\hline \multicolumn{6}{|c|}{ * Charcoal dates } \\
\hline \multicolumn{6}{|c|}{${ }^{* *}$ Pottery temper dates (internal part, oxygen, $400^{\circ} \mathrm{C}$ ) } \\
\hline
\end{tabular}

Tab. 1. Radiocarbon dates of the earliest Neolithic complexes of the Russian Far East and Siberia. 


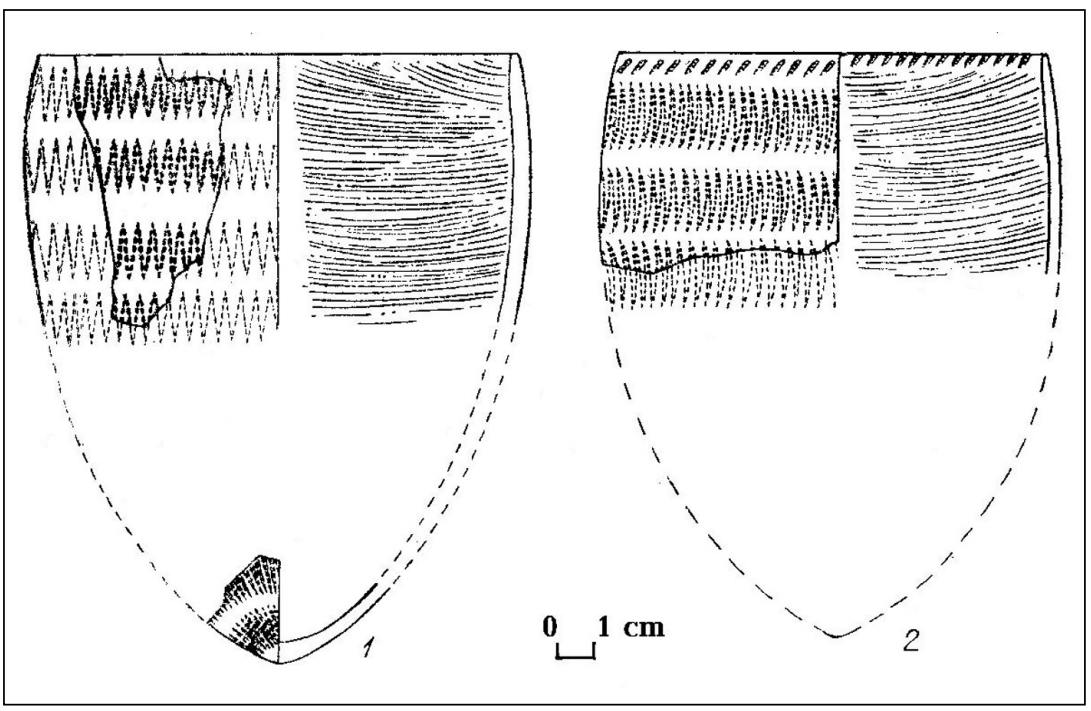

Fig. 7. The Ust-Karenga complex pots from the Ust-Karenga site (after Vetrov 1985).

The tentative determinations of the TL age of the Gasya site pottery are between 13460 and $8580 \mathrm{ca}$ lendar years BP (cal BP) (Kuzmin et al. 2001). The TL dates span an overall age range of some 5000 years. The errors of the TL dates are up to about 1500 years. ${ }^{14} \mathrm{C}$ dates from the Gasya pottery range from c. $11900 \mathrm{BP}$ to c. $9020 \mathrm{BP}$. In order to compare the ${ }^{14} \mathrm{C}$ and $\mathrm{TL}$ dates, the former need to be calibrated. Generally, it was found that the calibrated ${ }^{14} \mathrm{C}$ and TL dates overlap (Kuzmin et al. 2001.947).

Thus, the ${ }^{14} \mathrm{C}$ dating of the earliest Neolithic cultural complexes of the Russian Far East and Siberia has allowed us to establish that pottery appeared in the Amur River basin at c. 13000 BP, or c. 14000$13600 \mathrm{cal} \mathrm{BC}$. In Siberia, the earliest pottery is dated to about $11000 \mathrm{BP}$, or $11200-10900 \mathrm{cal} \mathrm{BC}$. First results of an independent check by TL dating of the Osipovka complex pottery from the Gasya site support these age determinations.

\section{DISCUSSION}

One of the most important questions in the study of the earliest pottery is: "What was the purpose of the use of ceramic vessels?". To answer this question, we need to know the main aspects of the palaeoeconomy. This is, however, quite difficult to determine due to the lack of direct evidence of human economic activities in the Russian Far East (e.g. Kuzmin 1998b). At the Gromatukha site, the bones of ungulates (Cervus elaphus, Sus scrofa, Capreolus sp., and Equus sp.) and unidentified fishes were found (Okladnikov and Derevianko 1977). No fau- nal or plant remains have been recovered from the cultural layers of the Osipovka and Ust-Karenga complexes.

In this situation, it is possible to use archaeological data to evaluate how natural resources were utilized. At the Gasya site, several net-sinkers were found in the earliest Neolithic layer (Derevianko and Medvedev 1993.99-100; 1994. 92-93). The data available show that hunting and fishing were the primary economic activities at all of the three complexes. In this case, pottery may have been used for the cooking of meat and fish, as well as for fat extraction from anadromous salmonids in the Amur River basin, as was suggested by Medvedev (1995. 236). The earliest solid evidence of dryland agriculture in the Russian Far East is known only from the

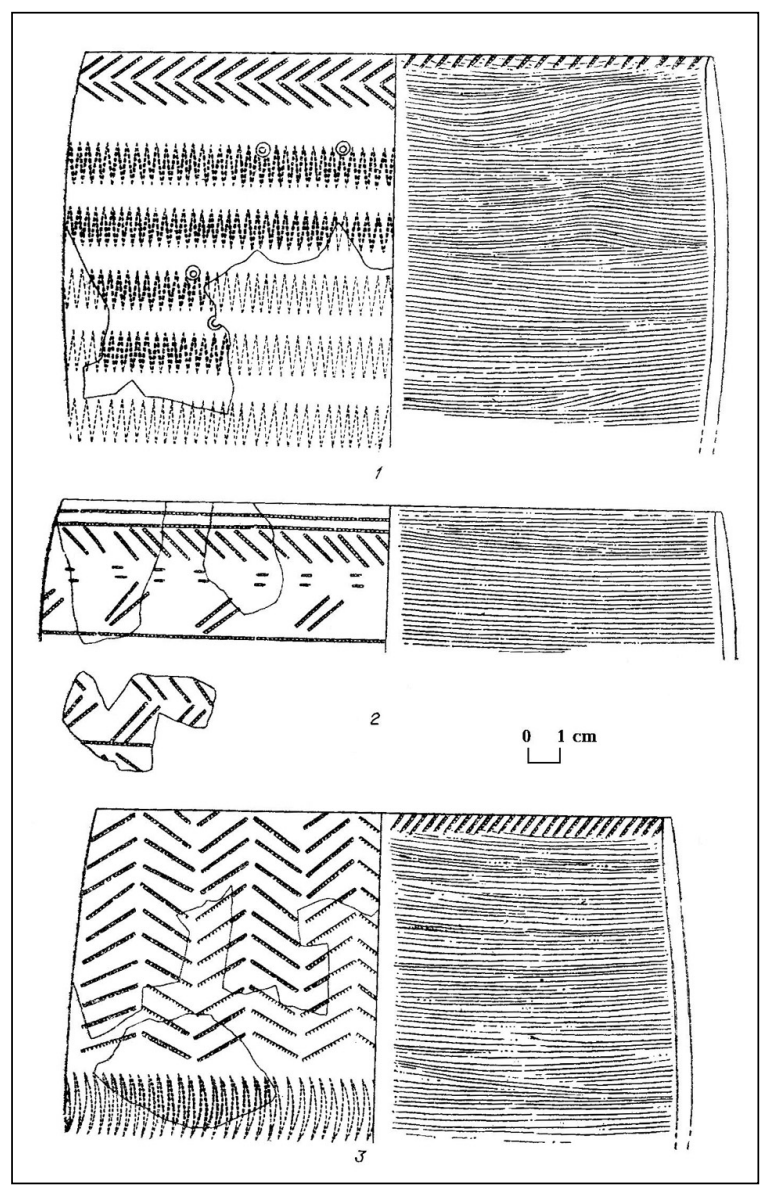

Fig. 8. The Ust-Karenga complex pottery from the Ust-Karenga site (after Vetrov 1985). 


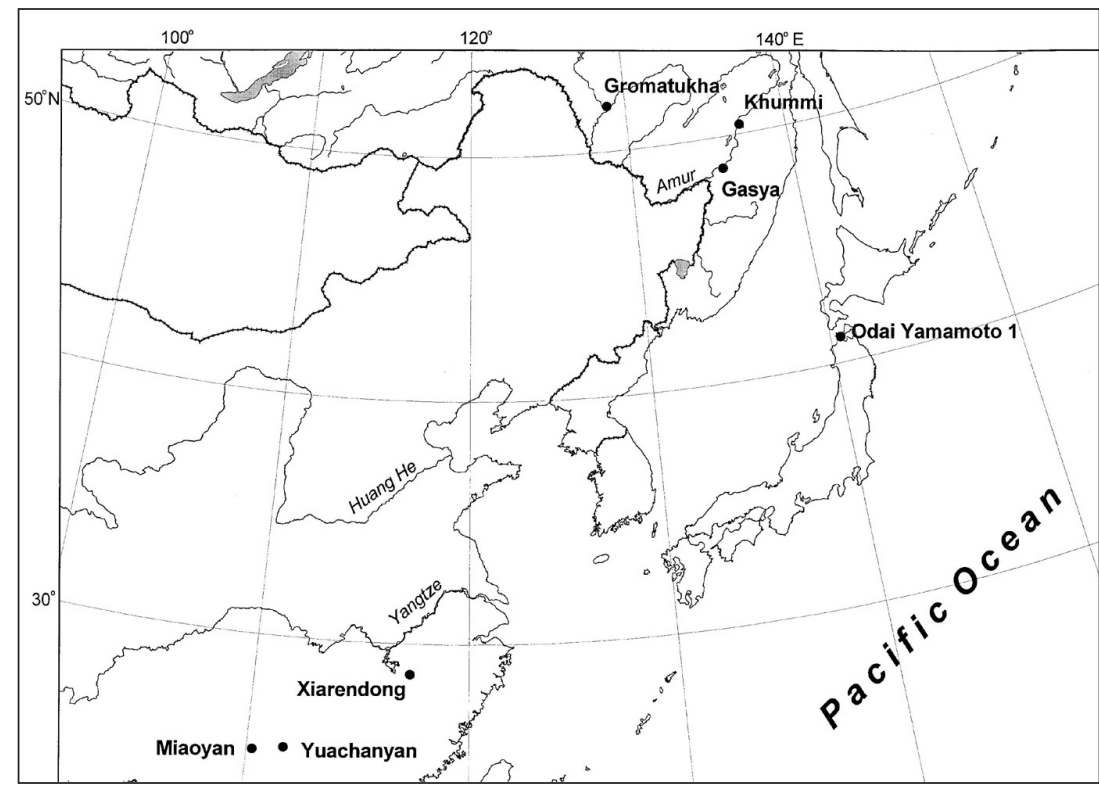

Fig. 9. The earliest Neolithic sites in East Asia.

Late Neolithic, at approximately 4200-3700 BP (Kuzmin et al. 1998b).

After the determination of the Late Glacial (i.e. pre$10000 \mathrm{BP}$ ) age of the Osipovka, Gromatukha, and Ust-Karenga complexes, it is necessary to compare it with adjacent East Asia. There are two regions outside the Russian Far East with pre-12 000 BP pottery: southern China and Japan (Fig. 9). In southern China, the earliest published Neolithic ${ }^{14} \mathrm{C}$ dates, run on organic remains in pottery, are known from the Miaoyan site in Guangxi Province, layer 5: $15220 \pm$ $260 \mathrm{BP}$ (BA94137b) and 15120 $\pm 500 \mathrm{BP}$ (BA94137a) (Zhao and Wu 2000). At the Yuchanyan site in Hunan Province, the earliest pottery-associated charcoal ${ }^{14} \mathrm{C}$ date is $13680 \pm 270 \mathrm{BP}(\mathrm{BA} 95058)$, and the organic remains in the pottery date to $14390 \pm 230$ BP (BA95057b) and $11970 \pm 120$ BP (BA95057a) (Zhao and Wu 2000).

The early ${ }^{14} \mathrm{C}$ value for the Xianrendong site in Jiangxi Province (zone 2B1), 14185 \pm 290 BP (BA93181) (MacNeish and Libby 1995), should be excluded from consideration due to possible mixture of cultural materials. As was emphasized by Zhang (1999. 6-7), the early ${ }^{14} \mathrm{C}$ dates from Xiarendong, which range from between $19780 \pm 360 \mathrm{BP}$ (BA95136) and $15050 \pm 60 \mathrm{BP}$ (UCR 3555), should be rejected, and the youngest ${ }^{14} \mathrm{C}$ value, $12430 \pm 80 \mathrm{BP}$ (UCR 3561) from zone $3 \mathrm{~B} 1$, is the most reliable age estimate for the earliest Neolithic component from this site.

In Japan, the earliest site with pottery is Odai Yamamoto 1 in northern Honshu (Aomori Prefecture).
Food adhesions on the pottery surface were dated to $13780 \pm 170$ BP (NUTA-6510) and $13210 \pm 160 \mathrm{BP}$ (NUTA6515) (Taniguchi 1999). However, after averaging all of the Odai Yamamoto site ${ }^{14} \mathrm{C}$ dates, using calculation proposed by Long and Rippeteau (1974), the ${ }^{14} \mathrm{C}$ age for layer 4 was estimated as $13050 \pm$ $108 \mathrm{BP}$, and the ${ }^{14} \mathrm{C}$ age for layer 3 as $13170 \pm 56 \mathrm{BP}$. This gives us essentially the same age as for the Gasya and Khummi sites.

The lack of information on the stratigraphy does not allow us to accept the very early ${ }^{14} \mathrm{C}$ dates from the Miaoyan site, and critical evaluation of the dates is still necessary. Based on the solid data, it is possible to make a preliminary conclusion about the emergence of pottery at approximately the same time, c. $13000 \mathrm{BP}$ (c. $15600 \mathrm{cal} \mathrm{BP}$, or c. $13700 \mathrm{cal} \mathrm{BC}$ ), in several places within East Asia, such as Japan, southern China, and the Russian Far East (Fig. 9).

\section{CONCLUSION}

Both the Osipovka and Gromatukha cultures clearly represent the earliest Neolithic complexes in the Russian Far East, Siberia, and the adjacent territories of Korea and northeast China (or Manchuria). The calibrated ${ }^{14} \mathrm{C}$ age of the earliest charcoal dates falls within the time interval of c. 13990-12360 cal BC (c. 15940-14310 cal BP), shown as average values between the maximum and minimum calibrated ages for charcoal ${ }^{14} \mathrm{C}$ dates in Table 1 . Thus, the Osipovka and Gromatukha complexes may be determined as Initial Neolithic (Medvedev 1995.236), and both complexes are most probably contemporaneous with the earliest Neolithic complexes in Japan and southern China. The Ust-Karenga culture, the oldest Neolithic complex in Siberia, dates to c. $11800-$ 10500 cal BC (c. $13800-12500$ cal BP). 


\begin{abstract}
I am grateful to Prof. Mihael Budja (Ljubljana, Slovenia) for the invitation to take part in the $8^{\text {th }}$ International Seminar "The Neolithization of Eurasia - Perspectives from pottery" held at the University of Ljubljana in November 2001, and for the opportunity to share new information about the age of pottery in East Asia. I am especially grateful to Dr. Zhang Chi (Beijing, China) and Dr. Charles T. Keally (Tokyo, Japan) for the updated information they provided on the age of the earliest pottery in China and Japan. I am very thankful to Mr. Sergei K. Vasiliev (Novosibirsk, Russia) for bone determinations from the Gromatukha site. I am also grateful to colleagues who helped in the study of the geoarchaeology of the earliest Neolithic complexes of the Russian Far East. Among them are: Profs. Anatoly P. Derevianko and Vitaly E. Medvedev, and Dr. Andrei V. Tabarev (Novosibirsk); Dr. Victor M. Vetrov (Irkutsk, Russia); Drs. Zoya S. Lapshina and Igor Y. Shevkamud (Khabarovsk, Russia); Dr. Boris S. Sapunov and Mr. Nikolai N. Zaitsev (Blagoveschensk, Russia); Drs. A. J. Timothy Jull, George S. Burr, Douglas J. Donahue, and Mrs. Jeanette M. O'Malley (Tuscon, AZ, USA); and Drs. Michael J. Tite and Richard Bailey (Oxford, England). I am thankful to Dr. Vyacheslav N. Dementiev and Ms. Anastasia V. Abdulmanova (Novosibirsk) for help in Figures preparation. Finally, I am grateful to Dr. Susan G. Keates (Oxford) for corrections of the grammar and some comments. This research, conducted from 1996 to 2000, was made possible with the support of research and travel grants received from several Foundations, including the Russian Foundation for Fundamental Investigations (RFFI), \# 96-06-80688 and 99-06-80348; International Science Foundation (Soros Fund) (1995); IREX (1995); the United States National Science Foundation (U.S. NSF), \# EAR95-08413 and EAR 97-30699; the Japan Foundation (1996); the Fulbright Program, \# 21230 (1997), the BK21 Fund, Republic of Korea (2000), and the Korea Foundation (2002).
\end{abstract}

$\therefore$

\title{
REFERENCES
}

BARNES G. L. 1999. The Rise of Civilization in East Asia: The Archaeology of China, Korea and Japan. Thames and Hudson, London.

CHARD C. E. 1974. Northeast Asia in Prehistory. University of Wisconsin Press, Madison, Wisconsin.

DEREVIANKO A. P. and MEDVEDEV V. E. 1992a. The Study of the Gasya Site (General Information, Preliminary Results of 1975 Excavations). Institute of History, Philology, and Philosophy, Siberian Branch of the USSR Academy of Sciences, Novosibirsk (in Russian).

1992b. The Study of the Gasya Site (Preliminary Results of 1976 Excavations). Institute of History, Philology, and Philosophy, Siberian Branch of the USSR Academy of Sciences, Novosibirsk (in Russian).

1993. The Study of the Gasya Site (Preliminary Results of 1980 Excavations). Institute of Archaeology and Ethnography, Siberian Branch of the Russian Academy of Sciences, Novosibirsk (in Russian).

1994. The Study of the Gasya Site (Preliminary Results of 1986-1987 Excavations). Institute of
Archaeology and Ethnography, Siberian Branch of the Russian Academy of Sciences, Novosibirsk (in Russian).

1995a. The Study of the Gasya Site (Preliminary Results of 1989-1990 Excavations). Institute of Archaeology and Ethnography, Siberian Branch of the Russian Academy of Sciences, Novosibirsk (in Russian).

1995b. The Amur River Basin as One of the Earliest Centers of Ceramics in the Far East. In H. Kajiwara (ed.), The Origin of Ceramics in East Asia and the Far East: 13-25.

GERASIMOV M. M. 1928. New Sites of the Prehistoric People of Stone Age near the City of Khabarovsk. Proceedings of the East Siberian Branch of the Russian Geographical Society 53: 135-140 (in Russian).

JULL A. J. T., BURR G. S., DEREVIANKO A. P., KUZMIN Y. V. and SHEVKAMUD I. Y. 2001. Radiocarbon Chronology of the Paleolithic-Neolithic Transition in the Amur River Basin (Russian Far East). In A. P. Derevianko and G. I. Medvedev (eds.), Current Problems of the Eurasian Paleolithic Studies: 140-142. (in Russian). 
JULL A. J. T., O'MALLEY J. M., BIDDULPH D. L., DEREVIANKO A. P., KUZMIN Y. V., MEDVEDEV V. E., TABAREV A. V., ZENIN V. N., VETROV V. M., LAPSHINA Z. S., GARKOVIK A. V., and ZHUSHCHIKHOVSKAYA I. S. 1998. Radiocarbon Chronology of the Earliest Neolithic Cultures of the Southern Russian Far East and Transbaikal Based on Direct Pottery Dating by Accelerator Mass Spectrometry. In A. P. Derevianko (ed.), Palaeoecology of the Pleistocene and the Stone Age Cultures of Northern Asia and Adjacent Regions 2: 63-68 (in Russian).

KUZMIN Y. V. 1995. People and Environment in the Russian Far East from Paleolithic to Middle Ages: Chronology, Paleogeography, Interaction. GeoJournal 35(1): 79-83.

1997. Pleistocene Geoarchaeology of the Russian Far East: Updated Results. Anthropologie (Brno) 35(2): 75-80.

1998a (ed.). Radiocarbon Chronology of the Stone Age of Northeast Asia. Pacific Institute of Geography, Far Eastern Branch of the Russian Academy of Sciences, Vladivostok.

1998b. Wetlands-Associated Sites in the Russian Far East: A Review of Environment, Chronology, and Paleoeconomy. In K. Bemick (ed.), Hidden Dimensions: The Cultural Significance of Wetland Archaeology: 56-63.

KUZMIN Y. V., HALL S., TITE M. S., BAILEY R., O'MALLEY J. M., and MEDVEDEV V. E. 2001. Radiocarbon and Thermoluminescence Dating of the Pottery from the Early Neolithic Site of Gasya (Russian Far East): Initial Results. Quaternary Science Reviews 20: 945-948.

KUZMIN Y. V. and JULL A. J. T. 1997. AMS Radiocarbon Dating of the Paleolithic-Neolithic Transition in the Russian Far East. Current Research in the Pleistocene 14: 46-48.

KUZMIN Y. V., JULL A. J. T. LAPSHINA Z. S. and MEDVEDEV V. E. 1997. Radiocarbon AMS Dating of the Ancient Sites with Earliest Pottery from the Russian Far East. Nuclear Instruments and Methods in Physics Research, Section B: Beam Interactions with Materials and Atoms 123: 496-497.

KUZMIN Y. V., JULL A. J. T. ORLOVA L. A. and SULERZHITSKY L. D. 1998a. Radiocarbon Chronology of the Stone Age Cultures, Russian Far East. Radiocarbon 40(2): 675-686.
KUZMIN Y. V., JULL A. J. T. and JONES G. A. 1998b. Early Agriculture in Primorye, Russian Far East: New Radiocarbon and Pollen Data from Late Neolithic Sites. Journal of Archaeological Science 25(8): 813-816.

KUZMIN Y. V. and ORLOVA L. A. 2000. The Neolithization of Siberia and the Russian Far East: Radiocarbon Evidence. Antiquity 74(284): 356-365.

LAPSHINA Z. S. 1998. The Ceramics of the Early Horizon of Khummi Site in the Lower Amur River Basin. In A. R. Artemiev (ed.), Historical-Cultural Contacts between Aborigines of the Pacific Coast of North Western America and North Eastern Asia: 191-200 (in Russian).

1999. The Antiquities of Lake Khummi. Amur Geographic Society, Khabarovsk (in Russian).

LONG A. and RIPPETEAU B. 1974. Testing Contemporaneity and Averaging Radiocarbon Dates. American Antiquity 39(2): 205-215.

MacNEISH R. S. and LIBBY J. G. (eds.). 1995. Origins of Rice Agriculture: The Preliminary Report of the Sino-American Jiangxi (PRC) Project SAJOR. Publications in Anthropology No. 13.

MEDVEDEV V. E. 1995. On the Problem of the Initial and Early Neolithic on the Lower Amur. In A. P. Derevianko and V. E. Larichev (eds.), The Review of Results of Field and Laboratory Research of Archaeologis, Ethnographers, and Anthropologists of Siberia and Far East: 228-237 (in Russian).

O'MALLEY J. M., KUZMIN Y. V., BURR G. S., DONAHUE D. J. and JULL A. J. T. 1999. Direct Radiocarbon AMS Dating of the Earliest Pottery from the Russian Far East and Transbaikal. Mémoires de la Société Préhistorique Française 26: 19-24.

OKLADNIKOV A. P. 1936. About the Archaeological Studies in 1935 on the Amur River. Soviet Archaeo$\log y$ 1: 275-277 (in Russian).

1958. Archaeological Investigations on the Far East in 1955. Short Communications of the Institute of History of the Material Culture, USSR Academy of Sciences 71: 109-118 (in Russian).

1980. About the Research of Archaeological Division of the Amur Complex Expedition in the Lower Amur River Basin in 1935. In A. P. Okladni- 
kov (ed.), Sources for Archaeology of the Northern Asia (1935-1976): 3-52 (in Russian).

OKLADNIKOV A. P. and DEREVIANKO A P. 1973. Ancient Past of Primorye and the Amur River Basin. Far Eastern Publishers, Vladivostok (in Russian).

1977. The Gromatukha Culture. Nauka Publishers, Novosibirsk (in Russian).

OKLADNIKOV A. P. and MEDVEDEV V. E. 1983. The Excavations of the Multilayered Site Gasya on the Lower Amur River Basin. Bulletin of the Siberian Branch of the USSR Academy of Sciences 20(1): 93-97 (in Russian).

SHEVKAMUD I. Y. 1997. New Research Concerning the Osipovskaya Culture in the Amur River Basin. Quarterly of Archaeological Studies 44(175): 102109 (in Japanese with English Abstract).

STUIVER M. and REIMER P. J. 1993. Extended ${ }^{14} \mathrm{C}$ Data Base and Revised CALIB 3.0 ${ }^{14} \mathrm{C}$ Age Calibration Program. Radiocarbon 35(1): 215-230.

STUIVER M., REIMER P. J., BARD E., BECK J. W., BURR G. S., HUGHEN K. A., KROMER B., McCORMAC G., van der PLICHT J. and SPURK M. 1998. INTCAL98 Radiocarbon Age Calibration, 24,000-0 cal BP. Radiocarbon 40(3): 1041-1083.

SUSLOV S. P. 1961. Physical Geography of Asiatic Russia. W. H. Freeman, San Francisco, California.

TANIGUCHI Y. 1999. Archaeological Research at the Odai Yamamoto 1 site: Summary. In Odai Yamamoto 1 Site Excavation Team (eds.), Archaeological Research at the Odai Yamamoto 1 Site: Inquiry into the Question of the End of the Paleolithic Culture and the Beginning of the Jomon Culture: 135-144.
TAYLOR R. E. 1987. Radiocarbon Dating: An Archaeological Perspective. Academic Press, Orlando, Florida.

VETROV V. M. 1985. Pottery of the Ust-Karenga Culture on the Vitim River. In P. B. Konovalov (ed.), Ancient Transbaikal and Its Cultural Contacts: 123130 (in Russian).

1995. Early Ceramics of the Stone Age Cultures of Upper Vitim. In H. Kajiwara (ed.), The Origin of Ceramics in East Asia and the Far East: 31-35.

1997. Ust-Karenga Culture and Its Place in the System of Archaeological Sites of Adjacent Regions. In G. I. Medvedev (ed.), Inter-Relations of the $\mathrm{Na}$ tions of Russia, Siberia, and Oriental Countries: History and Modernity 2: 176-180 (in Russian).

2000. Archaeology of the Stone Age of the Vitim Plateau (Cultures and Chronology). In G. I. Medvedev (ed.), Archaic and Traditional Cultures of Northeast Asia: Problems of Origins and Transcontinental Contacts: 28-36 (in Russian).

ZHANG C. 1999. The Mesolithic and the Neolithic in China. In M. Budja (ed.), Documenta Praehistorica 26: $1-13$.

ZHAO C. and WU X. 2000. The Dating of Chinese Early Pottery and Discussion of Some Related Problems. In M. Budja (ed.), Documenta Praehistorica 27: 233-239.

ZHUSHCHIKHOVSKAYA I. S. 1997a. On Early PotteryMaking in the Russian Far East. Asian Perspectives 36(2) 159-174.

1997b. Current Data on Late-Pleistocene/EarlyHolocene Ceramics in Russian Far East. Current Research in the Pleistocene 14: 89-91. 